\title{
KONSEP SYEIKH ABDURRAUF SINGKEL TENTANG KEMATIAN DALAM NASKAH LUBB AL-KASHF WA AL-BAYAN
}

\author{
Ahwan Mukarrom*
}

\begin{abstract}
The esoteric nature of Indonesian Islam during the $15^{\text {th }}-17^{\text {th }}$ centuries makes it possible for the debate on eschatological issues including the idea of death to flourish. Abdurrauf Singkel was among the Sufis to have lived in this dynamic century and was engaged in the debate on the issue of death. This paper is aimed at discussing his views about death particularly by referring to his Lubb al-K ashf wa al-B ayan. We discover that Singkel's treatment of death is related to such concepts of body, soul, salvation and human desire. We also find out that his views found a logical consonance with that of the J avanese manuscript called Serat Wirid idajat Djatinamun. Here human desire and destiny is symbolized in color; red symbolizes human's anger, black his evil deeds, yellow his mystical attitude, and white his happiness and inner tranquility. The basic argument of the two books is that control of one's desire during his/her lifetime will help determine his/her destiny in life to come.
\end{abstract}

Keywords: Tasawuf, Abdurrauf Singkel, death

\section{Pendahuluan}

Naskah ini disusun oleh seorang ulama besar dari Aceh yang, Syeikh Abdurrauf bin Ali alFansyuri atau juga dikenal dengan sebutan Abdurrauf Sinkel. Beliau lahir pada tahun $1620 \mathrm{M}$. dan wafat pada tahun 1690 M. ${ }^{1}$ Namun ada juga pendapat yang mengatakan bahwa beliau lahir pada tahun 1615 M. ${ }^{2}$ Nama Fansyur dinisbatkan kepada daerah kelahiran ibunya, Fansyur (Barus). Ayahnya, seorang ulama dari mancanegara (kemungkinan besar dari Arab) yang kemudian mula-mula memberi pelajaran agama kepada Abdurrauf muda. Kata-kata Sinkel atau al-Sinkilizdinisbatkan dengan daerah di mana beliau belajar ilmu agama dan kemudian menetap di sana.

Sebagaimana dimaklumi bahwa Aceh dan sekitarnya pada abad-abad keempat belas; kelima bekas dan keenambelas merupakan pusat kegiatan dakwah Islamiyah dan intelektual keislamanan.

Abdurrauf muda belajar agama mula-mula di daerah Sinkel, Aceh kepada seorang ulama, Syamsuddin Sumaterani, murid atau teman Hamzah Fansyuri, tokoh aliran tasawwuf Wujudiyah. Kemudian ia melanjutkan studi ke Makkah al-Mukarramah selama 19 tahun. Di sini beliau berguru di berbagai bidang dan cabang ilmu pengetahuan agama Islam kepada banyak ulama. Di antaranya adalah Abdullah; Ishaq bin Muhammad bin Jam'an; Abdurrahim bin al-Síddiq alKhas; Abdullah bin Muhammad al-Adani> Abdul Qadir al-Barqali> Ali bin Abd. Al-Qadir alTabari>Ahmad Qushasi>Ibrahim Kurani dll. Bidang-bidang ilmu yang beliau tekuni meliputi

${ }^{*}$ Fakultas Adab IAIN Sunan Ampel Surabaya

${ }^{1} \mathrm{H}$ arun Hadiwijono, Kebatinan Islam dalam Abad Enambelas (J akarta: BPK. G unung Mulia, 1971), 14.

${ }^{2}$ Mastuki HS. M.Ag. dkk. Intelektualisme Pesantren: Potret Tokoh dan Cakrawala Pemikiran di Era Pertumbuhan Pesantren (J akarta : Dian Pustaka, 2003), 83. 
Shari'gh (figh), hadith, ilmu kalam, tasawwwuf dan ilmu keagamaan esoteris pada umumnya. ${ }^{3}$

Dari sekian banyak guru/ulama tersebut di atas Ahmad Q ushasi>tokoh Tarekat Sattariyah merupakan murshid yang paling membekas pada pribadi Abdurrauf. Oleh sebab pula maka kemudian Abdurrauf mendapat mandat, legalitas (ijazah) untuk mengembangkan tarekatnya, Tarekat Sattariyah di Aceh dan wilayah sekitarnya. ${ }^{4}$

Saat beliau kembali ke Aceh, bias pertikaian antara pengikut aliran tasawwuf wujudiyah yang dikembangkan oleh Hamzah Fansyuri dan Syamsuddin Sumaterani dengan Syeikh Nuruddin al-Ranirimasih sangat berbekas di masyarakat bahkan di pusat pemerintahan. Namun demikian dengan kearifannya, Abdurrauf Sinkel tidak larut dalam pertikaian, akan tetapi justru memerankan diri sebagai mediator penengah antara kedua kubu tersebut. la mendapat kepercayaan dari Sultłøah S\$fiyatuddin, isteri almarhum Sultan Iskandar Tsani menjadi Qadiji Malik al-'Adil, atau mufti yang bertanggungjawab atas masalah-masalah keagamaan di Kerajaan Aceh $^{5}$

Konflik dua kutub antara pengikut faham wujudiyah yang dikembangkan Hamzah Fansyuri dengan faham yang dikembangan Nuruddin al-Ranirixini mencapai puncaknya pada periode Sultan Iskandar Tsani. Banyak pengkut aliran Wujudiłyah yang mengalami nasib tragis, dibunuh dan diusir. Buku-buku ajar faham Wujudiyah banyak yang dibakar karena menurut fatwa Syeikh Nuruddin al-Ranirispengikut faham ini diannggap kafir. Maka untuk tidak menambah problema di masyarakat, Syeikh Abdurrauf tidak berkenan membahas masalah Wujudiyah pada masa

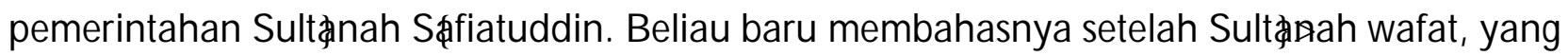
kesempatan tersebut dimanfaatkan untuk mengungkap kembali masalah-masalah itu. ${ }^{6}$

Sebagaimana tradisi akademik keilmuan tasawwwuf pada umumnya, Syeikh Abdurrauf Sinkel membina para murid sebagai kader untuk mengembangkan tarekat Sattaniyah di berbagai daerah baik di Nusantara maupun di Pattani (Thailand). Di antara murid-murid beliau tersebut adalah: Syeikh Burhanuddin Ulakan, dari Sumatera Barat; Syeikh Daud bin Abdullah Fattani (mungkin dari Thailand); Syeikh Muhammad Saleh al-Fattani; Syeh Yusuf Tajul Khalwati al Makassari> Syeikh Abdul Muhyi dari J awa Barat.

Syeikh Abdurrauf Sinkel telah menyusun banyak buku yang menyangkut berbagai disiplin ilmu agama Islam. Akan tetapi popularitas beliau sebagai pengarang adalah kemampuannya dalam bidang tasłwwuf. Buku-buku karya beliau disusun dalam bahasa Arab maupun bahasa Melayu. Di antara karya-karya beliau adalah:

1. Tanbih al-Mashy;

2. al-Dhikr;

3. Mir'at al-Tullab;

4. Tarjuman Mustafid;

5. Sullam al-Mustafidin;

6. al-Mawa'iz,al-Bida';

${ }^{3}$ bid., 87.

${ }^{4} \mathrm{H}$ awash Abdullah, Perkembangan Tashawwuf dan Tokoh-tokohnya di Nusantara (Surabaya: al-Ikhlas, 1980), 51. ${ }^{5}$ M. Wildan Yahya, M. Pd. Menyingkap Tabir Rahasia S piritual Syeikh Abduil Muhyi: Menapaki J ejak Para Tokoih Sufi Nusantara Abad XVII dan XVIII (Bandung: Refika Aditama, 2007), 96.

${ }^{6}$ A hmad Daudy, MA. Allah dan Manusia dalam Konsepsi Syeikh Nuruddin ar-Raniry (J akarta: Rajawali Press, 1983), 44. 
7. Bayan al-Arkan;

8. 'Umdatal-Muhtadin;

9. Kifayat al-M uhtajin;

10. Bayan Tajalli>

11. Daqaiø al-Khuruf,

12. Risalat Adab Murid akan Syeikh;

13. Majmu'>al-Masa'il;

14. Lubb al-Kashf wa al-Bayan;

15. Syair Ma'rifat. ${ }^{7}$

16. Tafsir Abdurrauf (Tasfsir pertama dengan bahasa Melayu) ${ }^{8}$

Dalam kajian ini pembahasan akan difokuskan pada karya beliau, kitab Lubb al-Kashf wa al-Bayan lima>Yarab al-Muhtadłar bi al-A'yan. Namun karena secara substansial sangat bersinggungan dengan Bayan Tajalli> maka kitab Bayan Tajalli>akan dpergunakan untuk menambah penjelasan-penjelasan terkait dengan isi buku Lubb al-Kashf wa al-Bayan, suatu buku yang membahas jeni-jenis dhikr yang baik bagi orang dalam rangka menghadapi kematian. ${ }^{9}$

Adapun naskah yang menjadi oyek bahasan ini berasal dari koleksi Prof. Snouck H urgronye yang diterbitkan oleh P. Voorhoeve dan kemudian diterbitkan lagi oleh Lembaga Kebudayaan Indonesia dalam Majalah IImu Bahasa, IImu Bumi dan Kebudayaan Indonesia tahun 19551957. Demikian pula Bayan Tajalli karya Syeikh Abdurrauf ini juga diterbitkan oleh P. Voorhoeve yang diterbitkan ulang oleh Lembaga Kebudayaan Indonesia sebagaimana di atas.

Secara garis besar, isi naskah Lubb al-Kashf wa al-Bayan lima yarah al-Muhtadłar bi alA'yan (dalam kajian ini selanjutnya dipakai dengan sebutan Lubb al-Kashf wa al-Bayan) ini terbagi dalam dua bahasan pokok. Masing-masing adalah: Pertama, pembahasan tentang Allah, SWT dan hal-hal yang berhubungan dengan itu. Kedua, pembahasan tentang dua jeniskematian; yakni mati ikhtiyari łmati dalam kehidupan) dan maupun mati yang sebenarnya (lepasnya nyawa dari jasad) yang disebut dengan mati ittiranis

\section{Tentang Allah dan Hal-hal Terkait dengan-Nya.}

Sebagaimana judul di atas, fokus pebahasan studi ini adalah konsepsi beliau tentang kematian. Namun karena pembahasan tentang kematian dalam naskah Lubb al-Kashf wa alBayan ini sangat erat berkaitan dengan Allah 'Azz wa Jall dan makna kematian, baik mati sesungguhnya/hakiki maupun mati secara majazi yyang dsisebut ikhtiyani> maka sebelum membahas tentang makna kematian lebih dulu akan dibahas konsepsi tetang Allah secara ringkas.

Perihal pendapatnya tentang Allah, dimulai dengan bahasan tentang suatu i'iqad (keyakinan,) bahwa Allah tidak memiliki rupa, bentuk dan sifat sebagaimana rupa, bentuk dan sifat makhluq. Ini ditegaskan dengan menukil ayat al-Qur'an, Surat al-Shuюa;ayat 11. Artinya:

${ }^{7}$ Lembaga Kebudajaan Indonesia "Madjalah untuk IImu Bahasa, IImu Bumi dan Kebudajaan Indonesia”. J akarta: Lembaga Kebudajaan Indonesia, N omor 4, 1955-1957) J ilid LXXXV, 115.

${ }^{8}$ Karrel A. Steenbrink, Beberapa Aspek tentang Islam di Indonesia abad ke 19 (J akarta: Bulan Bintang, 1984), 123. ${ }^{9}$ Azyumardi Azra, MA. J aringan Ulama Timur Tengah dan Kepulauan Nusantara Abd XVII dan XVIII : A kar Pembaruan Islam Indonesia (J akarta: Prenada M edia, 2004), 238. 
"Tidak ada sesuatupun yang menyerupai-Nya." Di sisi lain beliau menyiitir hạdith Rasululah SAW. yang artinya: "Telah aku lihat Tuhanku pada sebaik-baiknya rupa." Secara sepintas kedua dalil naqli ini paradox. Al-Qur'an menyebut bahwa Allah tidak menyerupai apapun, sedang hadith menyiratkan adanya rupa yang baik.

Perihal sabda ini, Abdurrauf memberikan penjelasan (tafsiran) bahwa rupa, bentuk maupun sifat Allah tidak seperti rupa, bentuk dan sifat manusia, sebab itu semua hanyalah madhar (tempat penampakan) belaka. Adapun yang dimaksud dengan pernyataan itu adalah pada dasarnya hanyalah tajalli łpengejawantahan). Manusia ini hanyalah bayang-bayang-Nya. Artinya tidak ada bayang-bayang tanpa wujud aslinya.

Menurut Syeikh Abdurrauf Sinkel, Allah bertajalli dengan apa saja yang Dia kehendaki. Ketika Allah bertajalliædengan nur-Nya yang sha'sha'ani łmemancar dan berbaur dengan yang dipancari/disinari) maka niscaya tidak akan bisa dipandang. ${ }^{10}$

Konsepsi Abdurrauf tentang tajalli ini pada dasarnya bermula dari adanya pemahaman bahwa Allah sebagai Dzat mutlak ketika masih dalam wujud yang azali xtidak bisa diidrak, dihinggakan) berkeinginan untuk bisa dikenal makhluq, alam. Persepsi ini berdasar atas hæidith Qudsi>yang artinya: "Aku adalah perbendaharan yang tersembunyi. Aku ingin supaya dikenal, maka Aku ciptakan kejadian (alam) ini sehingga dengan itu mereka mengenal Aku.

Dalam konsepsinya tentang tajalli,>Abdurrauf mengakui adanya tujuh martabat (level) tajalliyatsebagaimana konsepsi para sufi lain di kalangan wujudiyah dan atau martabat tujuh. Masing-masing adalah: Pertama Ahđdiyah; kedua Wahфlah; ketiga Wabidiyah. Ketiga martabat tersebut dinamakan dengan martabat "keilahian". Kemudian, keempat martabat berikutnya adalah martabat alam arwab; kelima martabat alam mithal; keenam martabat alam ajsam; ketujuh martabat alam insan. Empat martabat ini (alam arwab; alam mithal; alam ajsam, insan) adalah martabat "kemanusiaan" yang sekaligus sebagai madhar (tempat dhahir Allah). ${ }^{11}$ Allah bisa diidrak (dihinggakan).

Selanjutnya, menurutAbdurrauf Allah Swt. memiliki tujuh sifat utama yang menjadi induk dari segala sifat. Tujuh sifat tersebut adalah : Sifat hayab; sifat 'ilm; sifat qudrah; sifat iradah; sifat sama'; sifat basăr dan sifat kalam. Dengan sifat hłyah itu maka disebutlah dengan hælyy; dengan sifat 'ilm, disebut 'alim; dengan sifat qudrat, disebut qodirun; dengan sifat iradat itu, disebut muridan; dengan sifat sama' itu, disebut sami'; dengn sifat basłar itu, disebut basipy, dengan sifat kalam itu disebut mutakallim. Dengan sifat-sifat tersebut Abdurrauf mengatakan bahwa manusia dan makhluk yang ada ini merupakan bayang-bayang dari "sifat" Allah Swt. Maka sesungguhnya bayang-bayag itu tiada lain dari esensi yang memiliki bayangan itu sendiri; bukan bayangan itu ada dengan sendirinya. Maka harus diingat bahwa bayangan yang (dianggap) ada ini tidak ada substansinya. Dengan kata lain "la ł̇yy, wa la>alim wa la øadir wa la murid wa la sami'>wa la> basip wa la mutakallim illa Alah." Artinya: Bahwasanya, tidak ada yang hidup, tidak ada yang mengetahui, tidak ada yang kuasa, tiada yang berkehendak, tidak ada yang mendengar, tidak ada yang melihat dan tidak ada yang berkata-kata kecuali Allah Swt.

Dengan demikian konsep beliau tentang Allah yang terkait dengan posisi manusia sebagai

${ }^{10}$ Abdurrauf Singkel, Lubb al-Kashf, 9.

${ }^{11}$ lbid., 10. 
(madhar) tempat penampakan, adalah tingkat kondisi tertentu di mana kesadaran manusia telah sampai puncak dakian setinggi-tinginya hingga sampai pada suatu perasaan di mana ia merasa "adam," tidak ada/kosong." Itulah mati Ikhtiyaxi>Kondisi ini adalah tenggelamnya diri pada dzikir kepada Allah dengan tiada putus-putusnya dengan mengucap kalimat tæyyibah (la łlah illa Alllah) dengan hati dan nafas yang tertahan disertai perasaan bahwa ia benar-benar sudah hapus dan tenggelam dalam kekosongan.

Di sini digunakan istilah 'adam' (tiada/kekosongan), bukan 'fana'? J adi barang siapa yang merasa dirinya "tidak ada" atau "kembali tiada" atau "kosong" dengan perasaan bahwa yang ada hanyalah Allah, maka itulah yang dinamakan mati ikhtiyani>ya sadar benar bahwa keberadaan dirinya di dunia ini hanya madhar dari wujuyd Allah semata. Tanpa wujud hakiki Allah, niscaya manusia di dunia ini tidak akan mawjud. Pendapat ini didasarkan atas suatu hłdith qudsi yang artinya: "Matilah engkau (ikhtiyari sebelum engkau mati (yang sebenarnya). Dengan itu, maka yang dinamakan i'tiqad (keyakinan) yang benar (sebagaimana disebut di atas) adalah berkeyakinan bahwa dirinya (manusia) hanya bayang-bayang Allah Swt., sebab Allah-lah yang memiliki wujud yang sebenarnya. ${ }^{12}$

Dengan konsepsi demikian, maka terintegrasi dua kesadaran. Pertama, manusia menyadari bahwa wujud (keberadaannya) hanya madhar (tempat penampakan) Allah karena berdasarkan konsep tajalliyatnya ia adalah pengejawantahan Allah yang terakhir. Kedua, adanya kesadaran bahwa dirinya (manusia) telah sampai pada puncak tingkat dakian yang 'adam' (kekosongan, tidak ada apa-apanya). Istilah yang digunakan dalam teks adalah mati "ikhtiyari"

\section{Tentang Kematian dan Hal-hal yang Terkait dengan Itu.}

Menurut Syeikh Abdurrauf Sinkel, mati itu ada dua macam. Masing-masing adalah: Pertama, mati ikhtiyan łsebagaimana diterangkan sebelumnya), yakni tenggelamnya diri pada keadaan kekosongan, adam. Kedua, mati idtirari,>mati sesungguhnya, yaitu lepasnya ruh dari jasad. ${ }^{13}$

Tentang kematian dan sakaratal-mawt, Syeikh Abdurrauf Sinkel merujuk kitab Tadhkirah karya Syeikh J amaluddin al-Kurtubi>Dikatakan bahwa jika seseorang sudah dekat dengan ajal akan datang kepadanya pasukan Iblis yang menyerupai diri sendiri atau anggota keluarganya. Dengan suatu provokasi mereka menyuruh masuk ke dalam kelompok agama Yahudi. Jika tidak tergoda dengan provokasi ini, maka datang berikutnya pasukan yang menggoda dengan provokasi untuk masuk agama Nasrani. Dan jika masih tidak tergoda, artinya Allah menghendaki memberi petunjuk kepada jalan yang lurus dan mati dalam keadaan muslim, maka datang kepadanya malaikat yang mengenyahkan pasukan Iblis tersebut. Malaikat kemudian menyampaikan salam dari Allah yang artinya: "Sejahtera bagimu wahai Wali Allah. Allah Swt. mengirimkan salam kepadamu." Maka setelah itu dicabutlah nyawanya. ${ }^{14}$

Pada situasi kritis demikian di mana para iblis terus-menerus mempengaruhi untuk masuk agama Yahudi atau Nasrani, maka kepadanya dianjurkan untuk secara konsisten dan

${ }^{12} \mid$ bid., 16.

${ }^{13}$ bid., 17.

${ }^{14}$ lbid., 18. 
berkesinambungan mengucap kalimat la łlah illa Allah. Kalimat ini dilafalkan dengan dzikir yang samar di hati sebagaimana biasa dilakukan dalam proses mati ikhtiyax $\$^{5}$ Tentu ini bukan pekerjaan mudah bagi orang yang tidak membiasakan diri membaca dzikir kalimat tayyibah sebagaimana proses mati ikhtiyani.y adi bisa dikatakan bahwa mati ikhtiyani itu merupakan latihan,

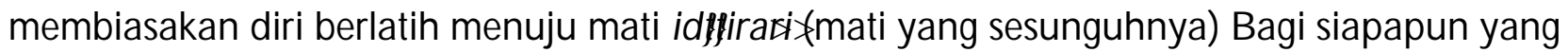
terbiasa tenggelam dalam 'adam, mati ikhtiyaxi niscaya tidak akan kesulitan dalam menghadapi sakaratal-mawt, mati idtilyaris

Konsepsi tentang kematian ini oleh Abdurrauf Sinkel bukan hanya dijelaskan di dalam Lubb al-Kashf wa al-Bayan saja akan tetapi justru dalam naskah Bayan Tajalli penjelasan tentang kematian dan hal-hal yang terkait dengannya mendapatkan tempat yang luas. Diakui juga oleh beliau bahwa penjelasan itu diambil dari Tadhkirah, yang terhadap kitab ini beliau tidak seluruhnya setuju, khususnya tentang dzikir yang "harus" diucapkan seseorang yang akan meninggal dunia. (mati idtzirarip

Di antara penjelasan-penjelasan tersebut adalah uraian tentang "godaan" bagi orang yang menghadapi sakarat al-mawt. Diceritakan bahwa ketika seseorang dalam kondisi kritis, menghadapi sakaratal-mawt selalu saja dihadapkan pada godaan-godaan.

Godaan tersebut, pertama datang kepadanya bayang-bayang hitam. Itulah Iblis. Oleh sebab itu dianjurkan untuk membaca kalimat la łab illa Allah. Huwa....Huwa... Huwa. Artinya :"Tidak ada Tuhan selain Allah. Dialah... Dialah. Dialah (Tuhan). Kemudian disusul dengan datangnya bayang-bayang merah. Itulah gambaran Nasrani. Dalam keadaan seperti itu dianjurkan membaca dzikir sebagaimana di atas. Kemudian muncul bayang-bayang berwarna kuning. Itu adalah Yahudi. Untuk itu dianjurkan membaca kalimat dzikir sebagaimana di atas. Dan jika kemudian yang datang adalah bayang-bayang putih, itulah sebenarnya Rasulullah Muhammad Saw. Untuk hal ini dianjurkan membaca kalimat Masha'`Allah kan min mu'min al-häqq. ${ }^{16}$ Artinya; “Masyaallah (dengan kehendak Allah), Sesungguhnya dia adalah dari golongan mukmin yang sebenarnya.

Dalam bagian selanjutnya disebutkan bahwasanya jika seseorang sudah dekat dengan ajalnya, maka datang dua makhluq setan yang kemudian duduk di sampingnya. Satu duduk di sebelah kanan, sedang setan yang lain duduk di sebelah kirinya. Setan yang berada di sebalah kanan merubah wujudnya menyerupai ayahnya dan mengajaknya untuk "mati" secara Nasrani. Sementara itu, setan lain yang berada di kanan berubah wujud menyerupai ibunya dan mengajak untuk "mati" secara Yahudi. Adapun kata-kata setan tersebut adalah sebagai bedrikut.

"Hai anakku! Bahwasanya perutku adalah bejanamu, dan air susuku ini adalah minumanmu, serta pahaku ini adalah tempat kedudukanmu, akan tetapi matilah engkau atas agama Yahudi, dan karena itulah sebaik-baik dari segala agama." ${ }^{17}$

$J$ ika seseorang tidak dapat tergoda oleh rayuan dan godaan setan-setan tersebut, dan jika Allah menghendakinya, niscaya Allah memalingkan kepada agama yang benar. Maka itulah yang diisyaratkan oleh firman Allah Ta'ala: “

\footnotetext{
15|bid., 18.

${ }^{16}$ Syeikh Abdurrauf Sinkel, "Bayan Tajalliy” dalam Majalah untuk IImu Bahasa, IImu Bumi dan kebudayaan Indonbesia (J akarta: Lembaga Kebudayan Indonesia, 1955-1957). Untuk bahasan selanjutnya digunakan dengan Bayan Tajalli> ${ }^{17}$ Singkel, B ayan Tajalli, 6 .
} 
Rabbana ła Łuzigh qulubana わa'd idh hadaytana. ${ }^{{ }^{8}}$ Artinya: "Wahai Tuhanku janganlah kiranya Kau cenderungkan kami kepada agama yang sesat pada ketika sakarałal-mawt kami, kemudian dari pada sudah Kau tunjukkan kepada kami jalan yang betul. Kemudian itu pula yang dimaksud dengan firman Allah: "wa habb lana min ladunk rahmah innak anta al-wahhab:" ${ }^{19}$ Artinya: "Tuhanku Kau anugerahi kiranya bagi kami rahmat dari hadlirat-Mu bahwasanya Engkau juga Tuhan yang menganugerahi." 20

Terhadap uraian tentang tanda-tanda datangnya ajal Syeikh Abdurrauf menentang keras pendapat dalam kitab Tijbb al-M ar' min Nafsihi_-Menurutnya, apapun juga kepandaian manusia kedatangan maut adalah rahasia Allah yang tidak bisa diketahui oleh sipapaun. Ini oleh beliau didasarkan atasal Qur-'an, Surat Luqman, ayat 34. yang artinya: "Dan tiada seorang manusiapun yang mengetahui di bumi mana dia akan mati. Dan bahwa Allah Ta'ala jua yang amat mengetahui akan segala sesuatu.:"

Menurut kitab ini ada beberapa hal yang bisa digunakan mendeteksi datangnya ajal, di antaranya adalah dengan melihat bayang-bayang dirinya di terik sinar matahari. A pabila bayangbayang tersebut tidak menampakkan kepala, niscaya yang bersangkutan hanya berumur tiga hari lagi. J ika terlihat bayang-bayang tak bertelinga, niscaya yang bersangkutan tinggal berumur satu bulan saja. J ika terlihat bayang-bayang tanpa kedua tangan, niscaya ia tinggal hidup satu tahun saja, dan seterusnya. ${ }^{21}$

Menurut Syeikh Abdurrauf Sinkel, apabila seseorang bisa mengetahui tanda-tanda akan datangnya ajal, itu sesungguhnya hanya secara kebetulan belaka, artinya berketepatan dengan taqdir Allah Ta'ala yang azali>Oleh sebab itu maka beliau mengatakan bahwa hal demikian itu kadang-kadang bisa diketahui, kadang-kadang tidak bisa diketahui. Orang yang dikehendaki Allah untuk mati dengan/secara baik, niscaya ia akan diberi petunjuk untuk melakukan amalanamalan yang soleh. $\mathrm{H}$ al ini sebagaimana sabda Rasulullah SAW. yang artinya :

"Bahwasanya Allah SWT apabila dikehendakinya kebajikan akan seseorang hamba-Nya, niscaya dikerjakan akan dia, Maka berdatang sembah sahabat kepadanya (Rasulullah). Wahai Rasulullah betapa perinya dikerjakan Allah akan dia taufik-Nya. Sabdanya: "Dikaruniainya akan dia taufiq pada berbuat amal soleh dahulu sebelum mati:"

Menurutnya, sebaik-baik tuntunan bagi seorang yang dekat ajal adalah dzikir la łlah illa> Alah". Hal ini didasarkan atas sabda Rasulullah, yang artinya: "ajari olehmu orang yang akan sakarabal-mawt itu dengan kalimat: la łab illa Allah. Dan juga didasarkan atas sabda yang lain bahwa siapa yang akhir hidupya mengucap kalimat la ilah illa Allah:, akan masuk ke dalam surga. Begitulah yang dimaksudkan oleh Syeikh Abdurrauf Sinkel jika mengetahui seseorang sudah dekat dengan ajal, bukan diajari dengan kalimat Laælah illa \$ uhammad Rasul>Allah. Huwa ... Huwa.. Huwa."22

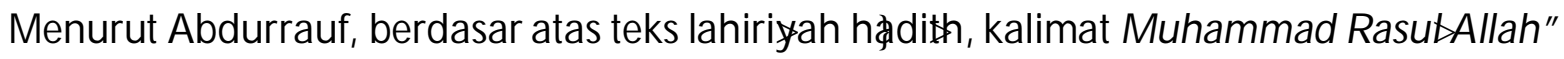

${ }^{18} \mathrm{QS}: 3$ (Ali Imron), 8.

${ }^{19} \mathrm{QS}$ S: 3 (Ali Imron), 8.

20Singkel, Bayan Tajalli, 11 .

${ }^{21}$ lbid., 15.

22Singkel, Lubb al-Kashf, 20. 
tidak perlu diajarkan pada orang yang sedang menghadapi sakaratal-mawt. ${ }^{23}$

\section{Sebuah Refleksi.}

Di akhir abad ke 16 dan pertengahan abad ke 17 setidaknya tercatat ada empat orang tokoh Kebatinan Islam (meminjam istilah Dr. Harun Hadiwijono) yang cukup berpengaruh di Sumatera Utara. Masing-masing adalah H amzah Fansyuri; Syamsuddin Sumaterani; Nuruddin al- Raniriølan Abdurrauf Sinkel. Antara kubu Hamzah Fansyuri, Syamsuddin Sumatrani di satu fihak dan Nururddin al-Raniriədi lain fihak pernah terjadi konflik berkepanjangan yang mencapai puncaknya pada masa pemerintahan Sultan Iskandar Tsani. Banyak jiwa melayang akibat fatwa Nuruddin al-Raniriyang menganggap pengikut aliran wujudiyah adalah sesat. ${ }^{24}$ Bahkan banyak karya-karya ilmiłah, buku-buku keagamaan yang beraliran wujudiyah dibakar dan dihancurkan. ${ }^{25}$ Saatkonflik ini terjadi Abdurrauf Sinkel masih di Makkah, menyelesaikan studinya.

Beliau kembali ke Aceh ketika situasi panas bias dari konflik ke dua kubu belum seluruhnya reda. Oleh sebab itulah maka Abdurrauf Sinkel lebih memerankan diri sebagai poros tengah, menghindari konflik, dan sedapat mungkin memberi alur pikiran yang menyinergikan kedua kubu. Buku-buku tersebut di atas adalah sebagian dari sekian banyak karya beliau yang masih dapat ditelusuri jejaknya. Salah satunya adalah Lubb al-Kashf wa al-Bayan, obyek studi ini.

Dalam perspektif Hemeneutika naskah Lubb al-Kashf wa al-Bayan bisa dikatakan sebagai potret kondisi dan situasi keberagamaan (Islam) Indonesia pada abad-abad 16-17 maupun 18. Sebagai elite sosial Syeikh Abdurrauf Sinkel telah berhasil mengkonstruk masyarakat. Ini terbukti dengan kepercayaan yang diberikan Sultăıah Sahafiatuddin kepadanya sebagai mufti kerajaan Islam A ceh serta kedudukannya sebagai ulama besar yang banyak memiliki santri dari berbagai penjuru.

Sebagaimana diketahui pada perio de tersebut di Indonesia banyak dijumpai karya-karya keagamaan (Islam) yang ditengarahi sebagai heterodox dan bahkan cenderung menyimpang (bidat, menurut H arun Hadiwijono). Bisa jadi kitab Tadhkirah, Tibb Nafs, dll masuk dalam kategori bidat tersebut. Maraknya karya dan aliran sesat demikian kiranya yang juga telah membuat pengarang dari Bonang, J awa Timur memberi peringatan keras kepada komunitas muslim yang baru untuk erkstra hati-hati dalam menuntut ilmu-ilmu kasampurnan pada umumnya yang memang menjamur. Buku dari Bonang ini kemudian distudi dan diterbitkan oleh B.J .0. Secrieke maupun G.W.J . Drewes. Itulah yang memotivasinya untuk menyusun buku sebagai rambu-rambu. Karya tersebut setelah diterbitkan di Belanda memiliki judul Het Boek van Bonang dan The Admonition of Seh Bari. Namun lepas apakah karya-karya tersebut heterodox yang cenderung menyimpang ataupun ortodox, tapi yang jelas wacana umum keagamaan yang esoterik demikian itulah yang sangat laris digemari masyarakat saat itu, termasuk di J awa.

Salah satu tema umum kehidupan esoterik masyarakat pada waktu itu adalah ilmu kasampurnan di mana kematian menjadi salah satu obyek vital bahasannya. Sehingga tepat sekali Abdurrauf Sinkel memberi semacam pencerahan terhadap masyarakattentang tema umum tersebut.

\footnotetext{
${ }^{23}$ bid., 21.

${ }^{24} \mathrm{H}$ arun Hadiwijono, Kebatinan Islam, 16.

${ }^{25}$ A hmad Daudy, Allah dan Manusia, 89.
} 
Berbeda dengan teks-teks esoterik yang mengambil topik tentang kematian di Sumatera Utara yang terlihat bersemangat dalam "menghabisi" Nasrani dan Yahudi, di J awa dapat kita jumpai dalam kondisi yang sedikit toleran. Terlihat misalnya pada beberapa kurun berikutnya pada Serat Wirid Hidajat Djati karya pujangga Ronggowarsito. Dalam Serat Wirid Hidajat Djati godaan-godaan yang datang menjelma menjadi bayang-bayang atau cahaya saat datangnya ajal selalu dinisbatkan kepada nafsu manusia yang terpendam dalam diri.

Dalam Kepustakaan Kejawen ini (Serat Wirid Hidajat Djati karya pujangga Ronggowarsito) cahaya hitam dinisbatkan dengan nafsu lawwamah; cahaya merah dinisbatkan dengan nafsu ammarah; cahaya kuning dinisbatkan dengan nafsu slufiyah, sedangkan cahaya putih dinisbatkan dengan nafsu mutthainnah. ${ }^{26}$ Terhadap nafsu-nafsu ini seyogyanya manusia selalu berusaha nuntuk mengendalikannya. Bagi mereka yang biasa mengekang (hawa) nafsu sepanjang hidup normalmnya, niscaya ia tidak akan mudah terpedaya pada kondisi kritis menghadapi kematian di mana nafsu-nafsu tersebut silih berganti menggoda.

Dengan membandingkan fenomena ilmu kasampurnan (baca= konsep tentang kematian dan kesiapan menghadapinya) antara Sumatera Utara dan J awa, dalam perspektif Sosisologi Agama bisa dikatakan bahwa di dalam situasi dsan kondisi konkrit agama akan menampakkan wajah yang konkrit pula. Artinya, dalam hal ini bahwa sentimen keagamaan dan perasaan umum masyarakat akan mempengaruhi keberagamaannya. ${ }^{27}$

Berdasar penelusuran tarhadap karya-karya esoterik di Nusantara, ternyata wacana tentang kemataian dan ilmu kasampurnan pernah menghiasi kepustakan Nusantara ini. Setuju atau tidak, suka atau tidak suka, siap atau tidak siapapun tentu akan berhadapan dengan fenomena ini. Oleh sebab itu apa yang pernah diwacanakan oleh para 'axif (ahli ma'rifat) seperti halnya yang terlihat dalam karya Lubb al-Kashf pada periode tersebut layak untuk diblow-up kembali dan digalakkan dewasa ini. Konkritnya manusia harus disadarkan lagi bahwa ia akan kembali ke asalnya, dan tidak mengokohkan diri baik keberadaan maupun kedudukannya di dunia fana ini. Kematian adalah suatu yang pasti datangnya pada tiap yang bernafas, dan tidak perlu dihadapi dengan penuh ketakutan. Semua fihak sesuai dengan fungsi dan kapasitasnya harus mengambil perannya dalam "memberanikan diri" menghadapi kenyataan tersebut. Masyarakat harus ditunjukkan ke arah "kebenaran" agar tidak tersesat di perjalanan kembali ke asalnya.

\section{Daftar Rujukan}

Abdullah, H awash. Perkembangan Tasawwuf dan Tokoh-tokohnya di Nusantara. Surabaya : al Ikhlas, 1980.

Azra, Azyumardi. J aringan Ulama Timur Tengah dan Kepulauan Nusantara Abad XVII \& XVIII. Akar Pembaruan Islam Indonesia. J akarta : Prenada Media, 2005.

Daudy, Ahmad. Allah dan Manusia dalam Konsepsi Syeikh Nuruddin ar Raniry. J akarta : Rajawali

${ }^{26}$ Simuh, Mistik Islam Kejawen Raden Ngabehi Ranggawarsita: Suatu Studi terhadap SratWirid Hidajat Djati ( ) akarta: UI Press, 1988), 287.

$27 \mathrm{~J}$ acquast Waardenburg, Populair and Offocial Religion as a Problem in Isamic Studies dalam Officaial and Populair Religion : Analysis of Theme for Religious S tudies, By Pieter Vrijhof and J acquast Waardenburg (ed), Newe York, Paris : The Hague Martinus Nijhoff 19789.) 245. 
Press, 1983.

Hadiwijono, Harun. Kebatinan Islam dalam Abad Enam Belas. J akarta Pusat: BPK. Gunung Mulia, 1971.

J acquast Waardenburg. Populair and Official Religion as a Problem in Islamic Studies. New York, Paris : The Hague Martinus Nijhoof. 1979.

Majalah untuk IImu Bahasa, IImu Bumi dan Kebudayaan Indonesia. J akarta: Lembaga Kebudayaan Indonesia, 1955.

Mastuki HS dkk. Intelektualisme Pesantren: Potret Tokoh dan Cakrawala Pemikiran di Era Pertumbuhan Pesantren. J akarta : Diva Pustaka, 2003.

Simuh. M istik Islam Kejawen Raden Ngabehi Ranggawarsita : Suatu Studi terhadap Serat Wirid Hidajat Djati. J akarta : UI Press, 1988.

Sinkel, Abdurrauf. Lubb'al-Kashf wa'al-Bayan dan Bayan Tajalli,Koleksi Prof. Snouck Hurgronye. Diterbitkan P. Voorhoeve.

Steenbrink, Karrel. Beberapa Aspek tentang Islam di Indonesia abad ke 19. J akarta : Bulan Bintang 1984.

Yahya, M. Wildan. Menyingkap Tabir Rahasia Spiritual Syeikh Abdul Muhyi: Menapaki J ejak Para Tokoh Sufi Nusantara Abad XVII \& XVIII. Bandung: Rineka Aditama, 2007. 